\title{
ANALYSIS ON THE USE OF ENGLISH IN ECONOMIC MATHEMATICS TEACHING AND LEARNING (EXPERIMENTAL STUDY IN UNIVERSITAS ADVENT INDONESIA)
}

\author{
Louise M. Saija, Ronny B. Sihotang \\ Louise_saija@yahoo.com,ron_cniners@yahoo.com
}

\begin{abstract}
English language is an International language. This makes the use of English in teachinglearning process in countries, where English is generally not a local medium of communication, become important. Mathematics is also very important for every student, but several previous research showed that students had difficulty in learning this subject. The purpose of this experimental study is to see the effectiveness of the use of English in teachinglearning process of economic mathematics towards economic undergraduate students. The result shows us that students who learn mathematics with English-medium system have better achievement than students who learn mathematics with local language. Another finding was students learn mathematics more enthusiastic when the teaching-learning process is made with the language they chose.
\end{abstract}

Keyword: English language, economic mathematics, teaching learning.

\begin{abstract}
Abstrak
Bahasa Inggris adalah bahasa internasional. Hal ini membuat penggunaan bahasa Inggris dalam proses belajar-mengajar di negara-negara, di mana bahasa Inggris pada umumnya bukan media komunikasi lokal, menjadi penting. Matematika juga sangat penting bagi setiap siswa, namun beberapa penelitian terdahulu menunjukkan bahwa siswa mengalami kesulitan dalam mempelajari subjek ini. Tujuan dari penelitian eksperimental ini adalah untuk melihat efektifitas penggunaan bahasa Inggris dalam proses belajar mengajar ekonomi matematika terhadap mahasiswa sarjana ekonomi. Hasil penelitian menunjukkan bahwa siswa yang belajar matematika dengan sistem bahasa Inggris menengah memiliki prestasi yang lebih baik daripada siswa yang belajar matematika dengan bahasa daerah. Temuan lain adalah siswa belajar matematika lebih antusias saat proses belajar mengajar dibuat dengan bahasa yang mereka pilih.
\end{abstract}

Kata kunci: bahasa inggris, matematika ekonomi, belajar mengajar.

\section{Introduction}

One thing that everyone ought to have is education. An educated person have greater opportunities and a brighter life. Begin with kindergarten, students continue their education up to high school. Afterward they will search for college and choose a major. There are various majors offered in college, and economics is one among those majors. Some students choose to study economics because it will prepare them for a specific career path, become a 
business man or woman, or become an accountant and pursue to be an accountant manager, or else. Other students choose economic major simply because they love economics.

Once economics is chosen, then students are faced with the economic curriculum. The first two years curriculum are designed to provide students with a strong ground of basic knowledge, and for the third and forth year students were encouraged to develop their own areas of expertise. One of the course for their strong basic knowledge was economic mathematics. Within this course students learn about some of the application of mathematics in economic field, and in the same time they can sharpen their logical thinking ability.

Many students in various level of education had difficulty in learning mathematics (Utomo, 2010, Pawestry et al., 2013, Elita, 2012, Harun, 2010), and this is one of the reasons for the occurence of mathematic anxiety. Mathematic anxiety is found in elementary students, in high school students, and in college students (Danesshamoz, S. et al., 2012). When those students become undergraduate students, or more specific economic majors, they brought their anxiety into economic mathematic class. According to Hadfield and Trujillo (1999), Ma (2003), D'Ailly and Bergering (1992) mathematics anxiety has to do with a sense of discomfort while required to work on mathematical problems and with fear and apprehension to specific math-related situations (Şahin, 2008). Furthermore, Furner \& Duffy (2002) and Hopko et. al. (2003) stated that poor performance in mathematic has been linked to an increase in mathematic anxiety (Şahin, 2008). More briefly, there were negative correlation between mathematic anxiety and mathematic performance (Daneshamooz, S. et al., 2012) or mathematic achievement (Wu, Sarah S. et al., 2012). For above reasons and due to minimize the mathematic anxiety, the usage of local language for teaching courses related to mathematic such as economic mathematics would be the preference of most undergraduate students.

Another course which is important for undergraduate students in the countries where English is generally not a local medium of communication is English. Actually, the freshmen already had English in high school, even from junior high school, but it was not enough for them. They have to take at least four credits unit for English. This is important since most of the books they will use is written in English. Learning English is different from learning with English-medium. If the difficulty in learning English considered as single difficulty, then the difficulty in English-medium learning considered with doubled difficulties, the second difficulty comes from learning the subject. So, in teaching-learning process of economic mathematics with English as the medium language, students could have doubled difficulties, difficulty in understanding the economic mathematics and English language. 
The aim of this research is to see whether English-medium system affected economic mathematics achievement. Will the students achievements in economic mathematics course become lower because of the teaching-learning process is in English medium? Another aim of this research is to see the relationship between the students English proficiency, showed through the Test of English as Foreign Language (TOEFL) scores, with their economics mathematics scores.

\section{Literature review}

\section{Economic Mathematics}

Economic mathematics is a course for undergraduate students in the faculty of economic. The prerequisite for this course are topics of mathematics which have the application in economic field. The purpose of studying this course is to give the knowledge of mathematic application in economic field, and to increase undergraduate students logical thinking. The table below gives some examples of the prerequisite mathematic topics students ought to understand and the application in economic field.

Table 1

\section{Mathematics, Topics and Application}

\begin{tabular}{|c|c|l|}
\hline No. & Mathematic Topics & \multicolumn{1}{|c|}{ Examples of The Application in Economic Field } \\
\hline 1. & Linear Equation & $\begin{array}{l}\text { Linear demand, supply, and consumption functions } \\
\text { and its graphs }\end{array}$ \\
\hline 2. & Lines intersection point & Break even analysis \\
\hline 3. & Quadratic equation & $\begin{array}{l}\text { Quadratic demand and supply functions, product } \\
\text { transformation curves }\end{array}$ \\
\hline 4. & $\begin{array}{c}\text { System of linear equations, } \\
\text { equations, and system of } \\
\text { quadratic equations }\end{array}$ & Market equilibrium \\
\hline 5. & $\begin{array}{c}\text { Logarithmic and exponential } \\
\text { equations }\end{array}$ & Compound interest \\
\hline 6. & Differential and Integral & Marginal cost, marginal revenue, point elasticity \\
\hline
\end{tabular}
(Weber, J. E., 1999, Kalangi, J. B., 2004).

The students retention on those prerequisite topics is good, then it is not difficult for them to understand its applications in economic field. But, if their retention on the prerequisite topics is not good enough, the lecturer has to re-explain those topics before discussing the applications in economic field; this is very important for the lecturers to do it because the 
economic mathematics course is highly related to another economic course such as micro economics, macro economics, business finance, or else. Furthermore, economic mathematic course is a prerequisite for statistic course in the economic faculty curriculum.

\section{English Medium}

An English-medium education system uses English as the primary medium of instruction - in particular where English is not the mother tongue of the students. This system was known as EMI (English Medium Instruction), or ICL (Integrating Content and Language), or CLIL (Content and Language Integrated Learning), or IP (Immersion Program) in Korea.

According to the research made by Crandall (1987), Brinton, Snow, \& Wesche (1989), Snow and Brinton (1997), and Mohan (1986), the idea of integrating content and language was first applied in the U.S. in order to assist immigrant students coming from countries where English was not the official language. This idea was further developed in Europe to promote foreign language learning and encouraging European university students to spend short-term study periods at universities outside European country, which was called Erasmus program (Fortanet, I., 2008).

Since learning the experiences of other universities could be a good point of departure to start new CLIL programs in many institutions (Fortanet, I., 2008), Universities in Asia, such as Taiwan and Indonesia have integrated languages included English in learning for years. One of the most important reasons is to prepare students to face globalization. Even for junior high schools and high schools, Indonesian government has supported International Standard Schools which utilize English-medium instruction since 2003 (Coleman, H., 2010).

\section{Research methodology}

This experimental study involved two groups of respondents (undergraduate students) within two classes in the faculty of economics at Universitas Advent Indonesia (UNAI). The first group or class experienced economic mathematics teaching and learning process with English-medium is called the experimental class, while the second group or class experienced economic mathematics teaching and learning process with local language (Indonesian) medium is called the control class. There were 41 active undergraduate students in the experimental class and 38 active undergraduate students in the control class. Before dividing the undergraduate students into classes, TOEFL was held and undergraduate 
students in the experimental class (class with English medium) need to reach TOEFL scores at least 400 .

Pretest was given before the teaching and learning process within those two classes started. The purpose of this pretest was to know the mathematic ability of the freshmen who came from various academic backgrounds. The result of the pretest also used for the students sitting arrangement in class. The purpose of the class sitting arrangement was to enable peer tutorial among the undergraduate students. After some period of teaching and learning, students had their individual tests (unit tests, mid test, and final test), and the average score for those individual tests were the considered scores to answer our research questions. To make the result more robust, we had calculated the average normalized gain given by Hake (Saija, 2010) and use it for the other considered scores within this research.

Compare-means analysis using t-test was used to answer the research question, that is to see whether the English-medium instruction affected the economic mathematic achievements. Comparing the pretest scores was needed to see whether the difference occurred in the beginning of the teaching and learning process. If so, then we ought to compare the average normalized gain to answer the research question. But if not, we use the average test scores for the compare-means analysis. Furthermore, a correlational analysis using Pearson's product moment coefficient and t-test was used to see the relationship between students English proficiency and the economic mathematics achievements. All those analysis were done through SPSS software.

\section{Results}

We have two things to analyze in this research that are:

1. The impact of English medium to students economic mathematics achievements.

Pretest was given before the teaching and learning process started. From the pretest scores we know the undergraduate students' initial mathematic knowledge. The null hypothesis we should test based on these scores was: There is no significant difference for the initial mathematic knowledge between the students in the class where the Englishmedium was implemented and the students in the class with local (Indonesian) language. Comparing two means analysis using SPSS produce an output table as follows: 
Table 2

\section{Comparison between Pretest Means}

\begin{tabular}{|l|l|l|l|l|l|l|}
\hline \multicolumn{3}{|c|}{} & \multicolumn{2}{l|}{$\begin{array}{l}\text { Levene test for equality } \\
\text { of variance }\end{array}$} & \multicolumn{4}{c|}{ t-test for equality of means } \\
\cline { 2 - 7 } & F & Sig. & T & df & $\begin{array}{l}\text { Sig } \\
(2 \text { tailed })\end{array}$ & $\begin{array}{l}\text { Mean } \\
\text { difference }\end{array}$ \\
\hline $\begin{array}{l}\text { Pretest } \\
\text { Equal } \\
\text { variances } \\
\text { assumed }\end{array}$ & 0,221 & 0,640 & 2,701 & 77 & 0,009 & 10,513 \\
\hline
\end{tabular}

According to table 2 above, it can be seen that the sig. value for Levene test is $0,640>$ $\alpha=0,05$, this means that the population variances of the pretest scores of those two classes were homogeny. Furthermore, the sig. value for the t-test is $0,009<\alpha=0,05$ indicated that there was a significant difference between the initial mathematics knowledge of the students in the class where the English-medium was implemented and the students in the class with local (Indonesian) language. Since the initial mathematics knowledge was different significantly, the gain scores were used for further analyzing.

The average normalized gain scores were analyzed using SPSS and the output was tabulated within two tables as follows:

Table 3

Group Statistics

\begin{tabular}{|c|c|c|c|c|c|}
\hline \multicolumn{2}{|c|}{ Group } & $\mathrm{N}$ & Mean & Std. deviation & Std error Mean \\
\hline$\overline{\text { GAIN }}$ & 1 & 41 & 0,6271 & 0,23023 & 0,03596 \\
\hline & 2 & 38 & 0,4784 & 0,28184 & 0,04572 \\
\hline
\end{tabular}

Table 4

Comparison between Gain Means

\begin{tabular}{|l|l|l|l|l|c|l|}
\hline \multirow{2}{*}{} & $\begin{array}{l}\text { Levene test for equality } \\
\text { of variance }\end{array}$ & \multicolumn{4}{c|}{ t-test for equality of means } \\
\cline { 2 - 7 } & F & Sig. & T & Df & $\begin{array}{c}\text { Sig } \\
\text { (2 tailed) }\end{array}$ & $\begin{array}{l}\text { Mean } \\
\text { difference }\end{array}$ \\
\hline $\begin{array}{l}\text { Eretest } \\
\text { vaual } \\
\text { vasiances } \\
\text { assumed }\end{array}$ & 2,385 & 0,127 & 2,575 & 77 & 0,012 & 0,26359 \\
\hline
\end{tabular}

According to the result in table 3 above, the undergraduate students in the class where English-medium was implemented have higher gain compared to the undergraduate students having economic mathematics course with local language. Furthermore, according to the 
result in table 4 , it can be seen that the sig. value for Levene test is $0,127>\alpha=0,05$, this means that the population variances of the gain scores of those two classes were homogeny. And the indication from the sig. value for the t-test was the economic mathematics gain scores of the students in the class where the English-medium was implemented were higher significantly compared to the economic mathematics gain scores of the students in the class with local (Indonesian) language. This tells us that English-medium does not give a negative impact to the students' economic mathematics achievements, or learning economic mathematics with English-medium will not lowering the undergraduate students achievements.

2. Correlation between students English proficiency and economic mathematics achievements

The undergraduate students English proficiency was measured through their TOEFL scores. To analyze the correlation between the undergraduate students English proficiency and their economic mathematic achievements we used the data from the experimental class, that is the class onto which the English medium was implemented. In this experimental class, the average of the undergraduate students TOEFL score was found to be equal 430. The data that the researches employed were the TOEFL scores which were given before the class started and the average test scores which were given during the teaching and learning period (within the semester). This table gives the SPSS output as tabulated below

Table 5

Correlation between English Proficiency and Achievements

\begin{tabular}{|lc|l|l|}
\hline & & TOEFL_SCORE & $\begin{array}{l}\text { TEST_EXPERI } \\
\text { MENT }\end{array}$ \\
\hline TOEFL_SCORE & Pearson Correlation & 1 & $0,474 * *$ \\
& Sig. (2-tailed) & & 0,002 \\
$\mathrm{~N}$ & 41 & 41 \\
\hline TEST EXP. & Pearson Correlation & $0,474 * *$ & 1 \\
& Sig. (2-tailed) & 0,002 & \\
& $\mathrm{~N}$ & 41 & 41 \\
\hline
\end{tabular}

**. Correlation is significant at the 0.01 level (2- tailed)

According to above table, the Pearson's product moment coefficient 0,474 indicates a positive and almost strong correlation, and since the significant value is $0,002<\alpha=0,05$, this 
means that the correlation is significant. So we can conclude that there was a positive and almost strong correlation significantly between the undergraduate students English proficiency and their economic mathematics achievements within the class where EMI was implemented.

\section{Discussion and Conclusion}

Implementing English medium in teaching will open the wider community of language among the students. As Wilkinson and Zegers (2010) stated that: "Cultures, and disciplinary communities do not stop at the borders of language communities. Student have to learn not only to acquire their learning through their mother tongue and 'national community', but also through second language and other communities, whether they are foreign or indigenous. Students may discover that they need to acquire knowledge of languages they had not even considered at the start of their studies". Furthermore, this statement gives us a direction that we have to implement the English medium instruction as soon as possible, specially for the undergraduate students, that is for the freshmen, and Universitas Advent Indonesia (UNAI) had already implemented this since the school year 2010-2011. Furthermore, this practice showed a progress if we compare it with the two-year pilot project 2005-2006, entitled "Proyecto de Incorporation de la Docencia en Inglés" in Spain where along the project, most teacher showed their preference to teach in English in the subjects in the last years before graduation, this is because they think that on that time student were more mature and could perceive the benefits of integrating content and language. In general, it was agreed that first and second year subjects might not be the most suitable in most degrees, since students are adapting themselves to the university's system, there are many students per course, and it is difficult to follow-up and get feedback from them, and because it is in these years that they take subjects of specific English for Academic Purposes, which trains them for the success of future subjects in English. (Fortanet, 2008).

The result in this research showed that the undergraduate students whose experienced English medium in the course economic mathematics have better achievement, compared with those who experienced the economic mathematics course with local language. This result is contrary with the idea from the suggestion of several studies made by Jochems, 1991; Dijcks, Dolmans, \& Glatz, 2001, that content knowledge may be less when learned through a foreign language as compared with learning through the mother tongue (Wilkinson $\&$ Zegers, 2010). This result and the similar result in the pilot project in Spain where most of 
the subject thought with EMI reached their objectives (Fortanet, 2010) can be used for other universities to improve EMI implementations on many more subjects.

A question arose whether the students faced learning difficulties and the result showed that the undergraduate students in this research still faced difficulties when learning the economic mathematic, but the peer tutorial system and scaffolding from the lecturer helped them to overcome those difficulties. This gives a contribution for the effectiveness of peer tutorial in economic mathematic teaching-learning process. One thing recorded from the observation was the students sometimes use Indonesian language in the peer tutorial discussion, and the lecturer also allowed them to use their mother language to express their difficulties through questions, even though the scaffolding was given in English.

Another finding in this research was students learn mathematics more enthusiastic when the teaching learning process was made with the language they chose, in this case English. No negative reaction has been observed from the students whose experienced EMI in the economic mathematics course. This result is in accord with the finding of Chang (2010) who implemented EMI onto 370 undergraduate students in Taiwan, that most of them did not show negative attitudes towards the courses. Moreover, most of the surveyed students agreed that English instruction helped them improve their English language proficiency especially in terms of listening. This result also in accord with the result found by Fortinet (2010) from the pilot project in Spain which has finished at the end of 2005 that no negative reaction has been observed from the students, even more some students have expressed their satisfaction and have appreciated their teachers' efforts.

\section{References}

Chang, Y-Y. (2010). English-Medium Instruction for Subject Courses in Tertiary Education: Reactions from Taiwanese Undergraduate Students. Taiwan International ESP Journal. Vol. 2:1, 55-84. www.tespa.org.tw/.../03\%20Englishmedium\%20instruction\% 20for\%20s

Coleman, H. (2013). Teaching Other Subjects Through English in Two Asian Nations : Teachers' Responses and Implications for Learners. http://www.academia.edu/705498/Teaching Other_Subjects_Through_English_In_Two_Asian_Nations_Teachers_Responses_a nd_Implications_for_Learners

Coleman, H. (2010). Dreams and Realities: Developing Countries and the English Language. www.britishcouncil.org

Daneshamooz, S. et al. (2012). Experimental Research about Effect of Mathematics Anxiety, Working Memory Capacity on Students' Mathematical Performance with Three 
Different Types of Learning Methods. ARPN Journal of Science and Technology, Vol. 2, No. 4, May 2012. http://www.ejournalofscience.org

Elita, S. (2012). Efektifitas Metode Jarimatika dalam Meningkatkan kemampuan Perkalian Bagi Anak Kesulitan Belajar. Jurnal ilmiah pendidikan Khusus, Volume 1. No. 1, Januari 2012. http://ejournal.unp.ac.id/index.php/jupekhu

Fortanet, I. (2008). Questions for Debate in English Medium Lecturing in Spain. In R. Wilkinson (Ed). Integrating Content and Language: Realizing Content and Language Integration in Higher Education. Nederland: Maastricht University. http://arno.unimaas.nl/show.cgi?fid=12521\#page $=47$

Harun, L. (2010). Eksperimentasi Pembelajaran Matematika dengan Pendekatan Contextual Teaching and Learning (CTL) Ditinjau dari Kemampuan Awal Siswa Kelas VII SMP Negeri Kabupaten Sukoharjo. Thesis. Surakarta.

Kalangi, J. B. (2004). Matematika Ekonomi \& Bisnis. Jakarta: Salemba Empat.

Pawestri, U. et al. (2013). Analisis Kesulitan Pembelajaran Matematika dengan Pengantar Bahasa Inggris pada materi pokok Bentuk Logaritma Kelas X Imersi SMA Negeri Karangpandan Karanganyar 2012/2013. Jurnal Pendidikan Matematika Solusi, Vol. 1, No. 1, Maret 2013

Şahin, F. Y. (2008). Mathematics Anxiety among 4th and 5th Grade Turkish Elementary

School Students. International Electronic Journal of Mathematic Education, Volume 3, No. 3, October 2008. www.iejme.com

Saija, L. (2010). "Pembelajaran Berbasis Masalah dengan Model Kooperatif MURDER untuk Meningkatkan Kemampuan Pemecahan Masalah Matematis Siswa SMA”. Thesis. Bandung: UPI

Utomo2, D. P. (2010). Pengetahuan Konseptual dan Prosedural dalam Pembelajaran Matematika. Seminar Nasional Matematika dan Pendidikan Matematika di Universitas Muhamadiyah Malang tanggal 30 Januari 2010.

Weber, J. (1999). Analisis Matematik, penerapan Bisnis dan Ekonomi. Jakarta: Erlangga

Wilkinson, R. Ang Zegers, V. (2010). Integrating Content and Language: Realizing Content and Language Integration in Higher Education. Nederland: Maastricht University.

Wu, Sarah S. et al. (2012). Mathematics Achievement and Anxiety and Their Relation to Internalizing and Externalizing Behaviors. Journal of Learning Disability, published online before print January 11, 2013 